\title{
Global Education Space: Russia and the World
}

\author{
Yury Moseykin \\ Faculty of Economy \\ Peoples' Friendship University of Russia (RUDN \\ University) \\ Moscow, Russian Federation \\ E-mail: moseykin_yun@rudn.university
}

\author{
Natalia Sakharchuk \\ Institute of World Economy and Business \\ Peoples' Friendship University of Russia (RUDN \\ University) \\ Moscow, Russian Federation \\ E-mail: sakharchuk_ns@rudn.university
}

\begin{abstract}
Modern education is developing in terms of globalization and integrative processes around the world, involving intensive interactions between states in different spheres of public life. Education from the category of national priorities of highly developed countries goes to the category of world priorities. Russia is no exclusion.
\end{abstract}

Keywords-Higher education; General trends in higher education; Globalization; Internationalization; Project 5-100

\section{INTRODUCTION}

The state of education in the modern world is complex and contradictory. The place of education in the life of society is largely determined by the role played by people's knowledge and their experience, skills, abilities, and the development of professional and personal qualities in the public development. This role began to increase in the second half of the 20th century, fundamentally changing in its last decades. The information revolution and the formation of a new type of social system - the information society - put information and knowledge at the forefront of social and economic development.

Changes in the sphere of education are inseparably linked with global processes and are occurring within the sociopolitical and economic life of the world community. An important feature of the development of modern education is its global character. This feature reflects the existence of integration processes in the modern world, intensive interactions between states in different spheres of public life. Education from the category of national priorities of highly developed countries goes to the category of world priorities.

\section{GLOBAL TRENDS IN EDUCATION}

\section{A. Internationalization of education}

Higher education is seen as a key factor in economic development in the context of the "knowledge economy" and socio-economic mobility. Despite the crisis, several governments are actively investing in higher education: France - \$11 billion, Germany - \$18, the US - \$21. Education is the third largest element of exports in Australia, bringing in $\$ 18$ billion in 2009. This sector is 50\% larger than tourism and annually shows growth (has already grown by $94 \%$ ). Foreign students bring more than 8.5 billion pounds to the UK economy. Between 2000 and 2008, the US share as the most popular country for training fell from $26 \%$ to $19 \%$ [1].

There are leading countries, which are mainly exporters of students, and leaders in the import of students. Now, there is a significant change in the structure of these countries: new leaders of import and export of educational services are emerging. The BRICS countries, for example, and the countries of South-East Asia in general (Malaysia, South Korea) are new candidates for leadership in both groups. Among the importers, English-speaking countries continue to dominate; the UK, USA, Canada and Australia remain the main ones. However, in the world ranking, China, Singapore and Malaysia are very close to them.

Around many universities in the world, the number of programs that are taught in English continues to grow dramatically. There are non-English speaking countries at universities where more than half of the programs are implemented in English, for example, in the Scandinavian countries.

There is a new requirement for competitive management of educational activities in Russia. If Russia wants to position itself in the education market, then it must be understood what proposals exist and are in demand on the education market. European countries, the United States, and Asian countries have different experiences and other suggestions. It is important to note that only in the last 15 years the number of international students in the world has grown from 1.9 million people. up to more than 3.5 million. It is a huge growth [2].

There is no doubt the timeliness of the process of forming global universities on the world education market. If earlier, the formation of leaders in the educational environment took place at the national level, then we are now we are talking about the existence of world leaders in the field of education.

This is partly due to globalization, while the described trend is independent supported by world student movements. But the main thing is the appearance of international academic ratings as a factor of the world education market. Ten years ago, who spoke of them? Yes, the Shanghai rating at that time already appeared, but it served for some local purposes: determining which universities to send Chinese students. 
Now, it is a universally recognized world rating, which, along with two other international academic ratings (the QS rating and the rating of THE), guided by the governments of all countries.

There are recognized leaders; they all are guided and there is a concentration of resources and projects around them. In China, for example, a lot of money is spent to finance national leaders. In Germany, there is a big project, the so-called excellence-initiative, which forms a pool of elite universities. At the same time, the university may not be a university of excellence in everything but only in a specific sphere and receive funds specifically for specialization. In Russia, this type of project does not exist yet, but there is another peculiarity: clusters of universities are singled out. There are three main ones: national universities with special status (for example, Moscow State University and St. Petersburg State University), federal universities and national research universities.

In 2013, there was a fourth cluster - a group of fifteen universities that won the competition as part of the project to improve the competitiveness of leading Russian universities among the world's leading research and educational centers.

\section{B. The Project 5-100 by 2020 in Russia}

The Russian system of higher professional education, which boasts Universities with traditions - as well as reflecting the pride of their own formidable academic reputations - now faces an arduous task: how to keep in step with the current pace of international development while not undermining its own excellent academic antecedents. The Russian Academic Excellence Project wants to tap into the full academic and research potential of Russian Universities while bolstering their positions in the global education market. The project, which is slated to last for eight years, was launched in May 2013 in accordance with the Presidential Decree of the Russian Federation № 599 on measures to realize state policy in the sphere of education and science [3].

The launch of the Project 5-100 sent a new satellite into orbit to assist in the process of revamping Russian higher education and make and giving it a contemporary. Past brainstorms and initiatives of the Russian government were effective, resulting in the creation of federal Universities and national research Universities.

The main goals of the Russian academic excellence project are:

- development and implementation of measures aimed at creating long-term competitive advantages for universities;

- internationalization in all spheres, development of infrastructure to recruit the best scientists, managers and students;

- $\quad$ production of world-class intellectual products;
- development of an outstanding academic reputation by doing breakthrough research and recruiting the world's leading scientists;

- bringing the university educational programs in line with the best international examples;

- development of cooperation between the academic sector, the industrial sector, and the business sector;

- increased export of educational services.

The main expected results of the Project 5-100 by 2020 is that Russia will have a group of contemporary university leaders with an effective management structure and a strong international academic reputation which meets global development trends that can quickly adapt to global changes:

- $\quad$ entry of at least five Russian universities into the top 100 of global education rankings (Times Higher Education World University Rankings, QS World University Rankings and Academic Rankings of World Universities (ARWU);

- at least $15 \%$ international students in each University's student body;

- $\quad$ at least $10 \%$ international faculty members.

- 21 Russian Universities are participants in Project 5100 and winners of the contest for government support. These universities are:

- Far Eastern Federal University (FEFU);

- National Research University - Higher School Of Economics (HSE);

- ITMO University;

- $\quad$ Saint-Petersburg Electrotechnical University (LETI);

- Kazan Federal University (KFU);

- National University Of Science And Technology MISIS (NUST MISIS);

- National Research Nuclear University "MEPHI" (MEPHI);

- Moscow Institute Of Physics And Technology (State University) (MIPT);

- Novosibirsk State University (National Research University) (NSU);

- Lobachevsky University (UNN);

- Samara National Research University;

- Peter The Great Saint-Petersburg Polytechnic University (SPBPU);

- $\quad$ National Research Tomsk State University (TSU);

- National Research Tomsk Polytechnic University (TPU); 
- Ural Federal University Named After The First President Of Russia B.N. Yeltsin (URFU);

- Immanuel Kant Baltic Federal University (IKBFU);

- I.M. Sechenov First Moscow State Medical University (Sechenov University);

- $\quad$ Siberian Federal University (SIBFU);

- $\quad$ South Ural State University (SUSU);

- RUDN University;

- University Of Tyumen.

"Excellence Initiatives", similar to the Russian Academic Excellence Project 5-100, are now among the in-vogue imperatives of many governments. Their aim is to improve the system of higher education and anchor their national universities to the highest positions in the global ratings. After all, universities with outstanding academic reputations are more likely to snag the hottest talent among lecturers, researchers and students, and indeed are viewed by many companies and organizations as virtual partners.

All such projects are connected with the allocation of leaders.

\section{Concentration}

The trend, which is rarely mentioned today, is the allocation of world cities as centers of attraction on the world education market. Not only are the universities themselvesworld centers but entire university cities. There is a very strong differentiation precisely in place. And if we talk about ratings in this vein, then TOP-10 includes, for example, Boston, Toronto, Paris, London and Zurich. They are catching up with Shanghai, Hong Kong and Singapore, which were not on this list before. From Moscow, Moscow is on the 38th place. St. Petersburg is not included in the TOP-50 of the most convenient and attractive for training cities in the world.

If we turn to the concept of a world class university (University Network World Class) [4][5], formulated more than 10 years ago, we can distinguish three of its main differences from others: concentration of resources, concentration of talents and effective management. Two of the three key characteristics of world universities are associated with concentration. Apparently, this is now one of the leading trends in world education - concentration.

\section{METHODS STUDY}

In the study, the authors used some methods such as a comparative analysis, synthesis, systematic approach and classification, historical method.

\section{CONCLUSION}

\section{A. Manifestations of globalization:}

- not only real, but also virtual mobility of people, capital and knowledge is increasing;
- the concept of "state-nation" and the state's ability to control economic and political transformations are blurred;

- the processes in culture become more complicated.

B. General trends in higher education [6]:

- globalization and transition to a knowledge society new requirements for universities;

- increase in demand for higher education;

- dilution of national frameworks of educational policy;

- the emergence of a market for higher education without borders;

- the need for a new educational policy.

"New horizons" of higher education and their impact on the functioning of universities:

- a massive increase in the enrollment of students;

- increase in the number and diversification of universities, training programs and their providers;

- development of scientific research and their financing - targeted, costly and highly competitive programs;

- changes in the relationship between the state and higher education;

- "accountable autonomy": substantive guidance instead of direct control;

- restrictions on public financing;

- quality problems and new information tools

- higher education becomes both the engine and the subject of globalization. Countries sharply increase investment in research universities.

\section{Internationalization Strategies [7]:}

- a coherent approach (Mutual understanding approach - Japan, Mexico, Korea and Spain can be attributed to countries implementing a coordinated approach);

- skilled migration approach - it can be noted: Austria, Finland, France, Hungary, Germany, Great Britain (for students from EU countries), Ireland, Holland, as well as Malta, Norway, Switzerland, Canada, USA (for students, receiving postgraduate education);

- revenue-forming approach - The countries implementing this approach include Australia, Great Britain (for students from non-EU countries), New Zealand and the USA (for students receiving higher education); 
- capacity building approach can be identified: the countries of Southeast and Central Asia (Malaysia, Hong Kong, China, Singapore, Indonesia, Vietnam, Thailand, etc.), Mexico and some countries of Eastern Europe).

D. The main directions of internationalization [8]:

- agreement on academic exchange (mobility of teachers and students);

- $\quad$ programs of double diplomas (bachelor's, master's);

- $\quad$ programs in foreign languages;

- $\quad$ double direction $(\mathrm{PhD})$;

- $\quad$ accreditation by foreign agencies;

- joint research;

- joint scientific events and publications;

- development, support and regulatory support of the branch network;

- $\quad$ advertising and promotion of educational services in foreign markets.

\section{E. Academic streams}

According to UNESCO:

- over the past 25 years, student mobility has increased by more than $300 \%$;

- $\quad$ by 2025 - about 9 million students will study abroad.

F. Some problems in this area:

- - the unresolved issue of the state and international recognition of diplomas of joint programs;

- - the structure and legal status of double degree programs has not been fully determined;

- - the quality assurance criteria are not always met;

- - bachelor's double degrees are less common than for masters.

G. Routes of implementation [9]:

- decentralization and democratization of governance;

- expansion of the autonomy of higher education institutions with simultaneous strengthening of their accountability to society;

- improvement of market models of organization, management and financing of education.

H. Consequences of internationalization for the management and financing of universities:

- $\quad$ significant increase in the provision of educational services;
- increasing pressure on public social spending at a pace that far outstrips the growth of public revenues.

\section{ACKNOWLEDGMENT}

This paper was financially supported by the Ministry of Education and Science of the Russian Federation on the program to improve the competitiveness of Peoples' Friendship University of Russia (RUDN University) among the world's leading research and education centers in the 2016-2020.

\section{REFERENCES}

[1] Hans de Wit, Trends and Drivers in Internationalization. March 20, 2011:

http://www.universityworldnews.com/article.php?story=2011031812 5131371.

[2] Kirwan William E., Meeting the Research University of the Future. March 22, 2010: [URL] https://www.aau.edu/WorkArea/DownloadAsset.aspx?id=10590.

[3] Official web-site of the Project $5-100$ by 2020 in Russia: [URL] http://5top100.com/about/more-about/.

[4] Jamil Salmi. The Challenge of Establishing the World Class Universities. All The World, 2009.

[5] The WC2 Network: [URL] http://www.wc2network.org/universities.

[6] Marginson S., The Rise of the Global University: 5 New Tensions May 30, 2010: [URL] http://chronicle.com/article/The-Rise-of-theGlobal/65694/

[7] Topical issues of the development of education in OECD countries / edited by M.V. Larionova. Moscow: The State University Higher School of Economics Publishing House - 152 pp.: [URL] https://www.hse.ru/mirror/pubs/lib/data/access/ram/ticket/18/1494786 679ba6f2545206662cefe8d86042cd149bb/questions_development_fo rmation.pdf.

[8] Alexander O. Grudzinski, Design-oriented university. Professional entrepreneurial organization of the university, Publishing House of the Nizhny Novgorod State University, pp. 370, 2004.

[9] Mass higher education: the new customer value, marketing, strategy, Federal Internet edition of "Capital of the country", December 7 , 2014: [URL] http://kapitalrus.ru/articles/article/massovoe_vysshee_obrazovanie_novaya_potreb itelskaya_cennost_marketing_strat/ 